RESIDENT

\& FELLOW

SECTION

Section Editor

Mitchell S.V. Elkind, MD, MS

Sunil Pradhan, MD, DM Gourav Goyal, MD

Address correspondence and reprint requests to Dr. Sunil Pradhan, Department of Neurology, Sanjay Gandhi Postgraduate Institute of Medical Sciences, Raebareli Road, Lucknow 226014, India drspradhan@rediffmail.com

\title{
Teaching NeuroImages: \\ Honeycomb appearance of the brain in a patient with Canavan disease
}

\section{Figure 1 Brain MRI}
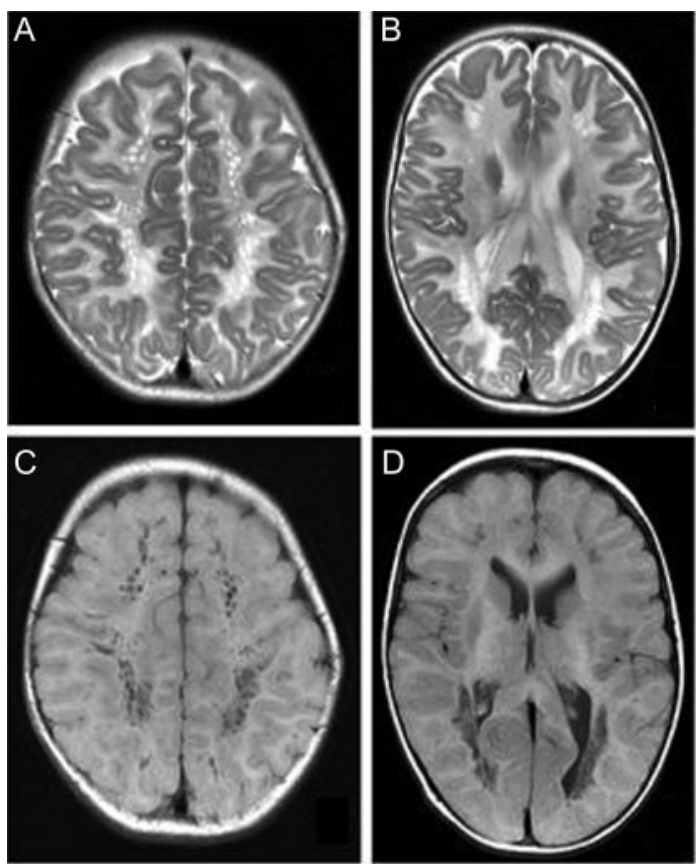

T2-weighted (A, B) and T1-weighted (C, D) MRI of the brain showing severe and diffuse T2 hyperintense and T1 hypointense signal changes in the white matter suggesting Canavan disease. Significant involvement of $U$ fibers is present. Multiple round or oval cystic changes within the white matter give a honeycomb appearance. The radial arrangement of these cystic spaces suggests dilatation of Virchow-Robin spaces due to spongiform degeneration of the white matter.

A 1-year-old girl presented with global developmental delay and generalized tonic seizures for 5 months. She was born of a nonconsanguineous marriage at full term but required resuscitation for 15 minutes during the postdelivery period. Her head circumference was $47 \mathrm{~cm}$ (90th percentile). The ocular fundi were normal. She was spastic bilaterally with hyperreflexia and extensor plantar responses. The white

\section{Figure 2 Brain magnetic resonance spectroscopy}

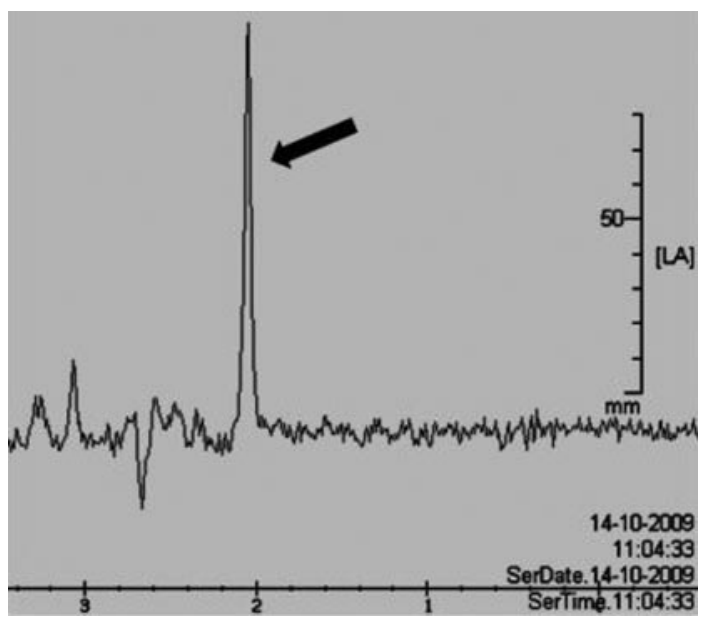

Single voxel (8-mL) magnetic resonance spectroscopy of the affected white matter of the brain showing the large $\mathrm{N}$-acetylaspartate peak (arrow).

matter changes on brain $\mathrm{MRI}^{1}$ (figure 1) and high $N$-acetylaspartate (NAA) peak on brain magnetic resonance spectroscopy (figure 2) and urine $\mathrm{NMR}^{2}$ suggested Canavan disease, an autosomal recessive dysmyelinating disease due to deficiency of the enzyme aspartoacylase that catalyzes breakdown of NAA. Its deficiency results in high NAA levels in serum and urine. The honeycomb appearance of the white matter may be due to leukodystrophy or, possibly, to an additional postnatal ischemic event.

\section{REFERENCES}

1. Brismar J, Brismar G, Gascon G, Ozand P. Canavan disease: CT and MR imaging of the brain. Am J Neuroradiol 1990;11:805-810.

2. Pinheiro GMS, Basso EA, Fiorin BC. A fast ${ }^{1} \mathrm{H}$ NMR spectroscopy procedure for quantitative determination of $\mathrm{N}$-acetylaspartate in urine samples. Clin Chim Acta 2009; 404:166-168. 


\section{Neurology}

\section{Teaching NeuroImages: Honeycomb appearance of the brain in a patient with Canavan disease}

Sunil Pradhan and Gourav Goyal

Neurology 2011;76; e68

DOI 10.1212/WNL.0b013e318212a887

\section{This information is current as of March 28, 2011}

\section{Updated Information \& Services}

References

Subspecialty Collections

Permissions \& Licensing

Reprints including high resolution figures, can be found at: http://n.neurology.org/content/76/13/e68.full

This article cites 2 articles, 1 of which you can access for free at: http://n.neurology.org/content/76/13/e68.full\#ref-list-1

This article, along with others on similar topics, appears in the following collection(s):

All Demyelinating disease (CNS)

http://n.neurology.org/cgi/collection/all_demyelinating_disease_cns Leukodystrophies

http://n.neurology.org/cgi/collection/leukodystrophies

Metabolic disease (inherited)

http://n.neurology.org/cgi/collection/metabolic_disease_inherited

MRI

http://n.neurology.org/cgi/collection/mri

MRS

http://n.neurology.org/cgi/collection/mrs

Information about reproducing this article in parts (figures,tables) or in its entirety can be found online at:

http://www.neurology.org/about/about_the_journal\#permissions

Information about ordering reprints can be found online:

http://n.neurology.org/subscribers/advertise

Neurology ${ }^{\circledR}$ is the official journal of the American Academy of Neurology. Published continuously since 1951, it is now a weekly with 48 issues per year. Copyright Copyright $@ 2011$ by AAN Enterprises, Inc.. All rights reserved. Print ISSN: 0028-3878. Online ISSN: 1526-632X.



